\title{
Orientasi Komitmen Ditinjau Dari Kepemimpinan Transformasional dan Kepercayaan Terhadap Manajemen
}

\author{
Sumaryono \\ Djamaludin Ancok \\ Fakultas Psikologi \\ Universitas Gadjah Mada
}

\begin{abstract}
This research aimed at finding Human Resources Management pattem in Indonesian goverment owned business organization (BUMN). Focus of the research were finding correlation pattem between commitment orientation and trust for management and transformational leadership. This research also assesed carrier-oriented commilment, leam-oriented commitment, and organizational-oriented commitment.

Data were collected from 208 employees a one BUMN in East Java. Three scales were used in this research: Orientation Commitment Scale, Trust for Management Scale, Transtor. mational Leadership Scale. Data were analysed thing multiple regression.

The resulls of the research are: a) Transformational Leadership and tust for management correlate with Commitment Orientation, b) Canier-Oriented Commitment was influenced by trust for management, c) Transformational Leadership and trust for management correlate with Tean-Oriented Commitment, d) Onganizational-Oriented Commitment was influenced by Trans. formational Leadership.
\end{abstract}

Key Words: Commitment Orientation, Carrier-oriente: Commitment, Team-oriented Commitment, Organizational-oriented Commitment, Thust for Managernent, Transformational Leadership.

\section{Pendahuluan}

$\mathrm{K}$ omitmen kerja memang memegang peran penting untuk tetap tegek berdirinya organisasi. Banyek bukti telah menunjukkan hal tersebut, termasuk kasus Lee lacocae dengen Chryslernya, Rini Suwandi dengan Astre Internasional, Cacuk dengan Telkomnya dan beberapa perusahaan kelas menengah lainnya. Sebaliknya ketiadaan komitmen kerja memang menjadi sumber petaka bagi kelangsungen organisasi. (Gross, 1996). Secara logika, hel tersebut wejar. Tanpa adanya kepedulian dari anggota, mana mungkin perusahaen akan berkembang. Apalagi bila kondisi organisesi sedang mengalami goncangan yang luer biasa. Bisa dibayangkan, bagaimana jadinya bila sebuah organisasi sebesar Telkom misalnya, tidak dihuni oleh orang-orang berkomitmen tinggi. Secara pasti dapat diramalkan kehancuran akan tiba, korupsi merebak, karyawan bekerja seenaknya, karyawan dengan leluasa keluar, dan ujung-ujungnya eksistensi perusahaan akan hilang.

Permesalehannya adaleh bagaimane 
sebenarnya membangun komitmen pada karyawan di Indonesia secara umum. Banyak faktor berpengarih dalam had ini, salah satunya faktor kepemimpinan dan kepercayaan terhadap manajemen. Hal ini dikarenakan oleh fenomena yang mengindikasikan bahwa tidak semua jajaran manajemen di berbagai organisasi d lindonesia mampu mengembangkan pola kepemimpinan dan membangun kepercayaan terhadap manajemen, sehingga tidak membangun komitmen kerja karyawan. Permasalahan lain tentunya berkaitan dengan fenomena yang terjadi.

Belajar dari berbagai kasus-kasus yang ada, diasumskan bahwa aspek kepemimpinan dan kepercayaan merupakan dua hal penting untuk mendukung munculnya model komitrmen yang tinggi. Hal ini menjadi sesuatu yang menarik apabila dikaitkan dengan era perubahan, Sebuah perubahan terjadi pada organisasi bisnis akan memiliki imbas yang cukup banyak. Salah satu hal yang akan berpengaruh adalah masalah kepernimpinan dan kepercayaan teihadap manajemen. Kedua hal tersebut tentunya akan membawa pengaruh terhadap komitmen kerja karyawan.

Komitmen kerja memang bukan sesuału yang sekaligus jadi tanpa sebab. Hal ini sudah terbukti bendasarkan berbagai fenomena yang ada di lingkungan Indonesia. Banyak perusahaan yang merasa bahwa karyawankaryawan yang dikelola dianggap sudah memiliki komitmen tinggi terhadap organisasi, namun kenyataan yang ada tingkat kinerjanya masih beium memuaskan. Hal ini perlu disadari, karena ukuran komitmen terhadap organisasi saat ini tidaklah sekedar byal atau tum-over yang rendah saja. Ukuran kinerja, justru merupakan suatu patokan yang sangat berarti dari proses komitmen (Bret, Crom \& Slocun, 1995). Optimalisasi kinerja merupakan suatu pertanda bahwa karyawan memiliki komitmen tinggi terhadap organisasi.

Perubahan paradigma dalam memaknai komitmen kerja ini tentunya tidaklah muncul dengan begitu saja. Hal ini tak lepas dari perubahan paradigma dalam fibsof manajerial dalam pengelolaan organisasi. Dewasa ini perkembangan model manajerial iebih terlokus pada model pemberdayaan manusia yang ada dan sudah mulai bergerak menuju model investasi manusia dabm organisasi (Miles \& Creed dalam Kramer \& Tyler, 1996).

Daiam dua model ini, secara prinsip manusia dalam organisasi dipandang sebagai sosok individu yang memiliki kesadaran dan keinginan untuk memberikan kontribusi terhadap organisasi. Lebih-lebih dalam pandangan model yang paling akhir, human investment model. Individu dalam model ini tidak hanya memiliki keinginan tersebut, tetapi juga memiliki kesadaran diri untuk selalu mengembangkan kemampuan diri, kompetensi, dan pemahaman terhadap isu-isu bisnis mutakhir. Selain itu, kebanyakan individu dalam model ini memang merasa bahwasetiap individu dalam organisasi layak dipercaya dan dapat mengembangkan interaksi inter-personal serta intra-organisasional. Inti dari model ini yaitu adanya penekanan kepercayaan terhadap kemampuan serta kemauan untuk berkembang pada dri para anggota organisasi.

implikasi dari asumsi tersebut di atas, komitrnen karyawan menjadi semakin jelas. Secara logika, komitmen baru akan terjadi manakala karyawan dipandang sebagai sosoik yang berarti atau sosok yang memiliki eksistensi. Hal ini wajar, karena karyawan dipandang sebagai sosok yang memiliki investasi dalam organisasi. Dalam konteks ini, investasi yang diberikan berupa kompetensi dan kemauan untuk berkembang.

Kondisi d atas, tentunya akan berkaitan dengan permasalahan kepercayaan terhadap manajemen dan model kepemimpinan yang berkembang dalam organisasi. Komitmen karyawan baru akan terbentuk manakala karyawan sebagai anggota organisasi merasa percaya bahwa kebijakan manajemen dan pola kepemimpinan yang ada memang mendukung situasi dan kondisi yang memungkinkan untuk munculnya kinerja optimal.

Sejalan dengan inti dari hasil penelitian tersebut, secara tegas Cummings dan Bromiley (dalam Kramer \& Tyler, 1996) mengemukakan bahwa keyakinan seorang 
terhadap pihak lain, atau dengan istilah lain disebut kepercayaan, akan berkaitan dengan komitmen orang tersebut. Menurut Kramer \& Goldman (dalam Kramer \& Tyler, 1996) menekankan suatu pernyataan bahwa komitmen merupakan refleksi dari perilaku mempercayai. Oleh karena itu, berdasarkan uraian torsebut, nampak bahwa komitmen karyawan cenderung memiliki keterkaitan dengan aspek kepercayaan karyawan terhadap manajemen.

Membahas masalah kepercayaan terhadap manajemen berarti membahas suatu hal yang tidak dapat terjadi dengan begitu saja. Tentunya kepercayaan terhadap manajemen tidaklah lepas dari pandangan karyawan atau bawahan terhadap segala proses yang dilakukan dan dijalankan oleh pihak manajemen, Oleh karena itu, pembahasan masalah ini tidak lepas pula dari model kepemimpinan. Kepercayaan terhadap manajemen akan bisa dlanggap baik oleh para bawahan manakala kebijakan para pemimpinnya sanggup memberikan kepuesan, Dalam konteks manajemen yang berlandaskan model human invesment, kepuasan karyawan tercapai apabila terjadi pemberdayaan para bawahan atau pengikut dan pengakuan atas kontribusi serta kemauan bawahan untuk berkembang (Miles \& Creed dalam Kramer \& Tyler, 1996; Yuki, 1998; Hughes, Ginnet \& Curphy, 1996)

Menurut beberapa kajian, proses kepemimpinan yang banyak berorientasi pada konsep seperti itu adalah proses kepemimpinan transformasional. Menurut Bass \& Avolio (1988), Bass, Avolio, \& Goodheim (1987) dan beberapa ahli lainnya, kepemimpinan transformasional memiliki keterkaitan yang positif terhadap kepuasan karyawan, kinerja karyawan, dan membuat bawahan merasa dihargai eksistensinya. Hal ini tentunya akan memberikan pandangan positif dan adanya kepercayaan terhadap kebijakan-kebijakan manajemen.

Secara konsep teoritis, salah satu aspek penting dalam kepemimpinan transformasional adalah kepercayaan. Dengan kata lain, seorang pemimpin baru dapat dikatakan memakai konsep kepemimpinan transformasional jïka sang pemimpin mampu menghasi|kan kepercayaan. Hal ini ditegaskan oleh Bass (1985) dalam konsep yang dikembangkannya.

Ditinjau dari karakteristik kepemimpinan transformasional yang diuraikan oleh Hughes, Ginnett, \& Curphy (1996), aspek kepercayaan tersebut bisa jadi sudah dikembangkan oleh sang pemimpin. Akan tetapl, dari sisi para pengikut aspek kepercayaan baru bisa diakui manakala d mata para pengikut kepercayaan tersebut memang sudah terasakan. Oleh karena itu, aspek kepercayaan terhadap manajemen tetap menjadl hal penting untuk ditonjolkan dalam penelitian ini.

Leblh lanjut, Podsakoff, MacKenzie, \& Bommer (1996) menegaskan bahwa perilaku kepemimpinan transformasional mempengaruhi aspek kepercayaan terhadap organisasi maupun komitmen. Hal ini berarti bahwa model kepemimplnan inl memang sosuai untuk paradigma manajemen yang berkembang saat ini dan memenuhi tuntutan dalam pengembangan kualitas manusia daam organisasi seperti yang digambarkan oleh Walker (1991) tentang isu-isu penting dalam pengelolaan manusia dalam organisasi.

Fenomena seperti itu sudah berkembang di indonesia. Salah satu penelitian yang ada menujukkan bahwa penerimaan ternadap seorang pemimpin yang menggunakan kaidah kepemimpinan transformational justru lebih memperlancar proses menghadapi perubahan d sebuah perusahaan (Irianto, 1991).

\section{Metode}

Subjek dalam penelitian ini adalah karyawan dari sebuah BUMN yang sudah bekerja dengan masa kerja minimal 5 tahun. Pemilihan organisasi dengan bentuk BUMN ini tentunya didasari dengan alasan yang kuat. Sebagaimana diketahui, banyak BUMN mulaj sadar untuk melakukan perubahan berdasarkan tuntutan zaman dan tuntutan era perubahan paradigma. Berdasarkan hal itu, 
tentunya ada perubahan paradigma dalam kepemimpinan dan budaya organisasi. Hal ini tentunya akan membawa dampak yang sangat luas, karena pola pengelolaan BUMN lama dengan pola pengelolaan BUMN yang baru banyak berbeda. Salah satu dampak diantaranya masalah komitmen. Hal itu dapat dipastikan akan ada, karena bisa jadi pola kepernimpinan lama yang cenderung feodal segera diganti.

Subjek yang ikut berpartisipasi dalam penelitian ini berjumtah 208 karyawan. Jumlah tersebut berkisar $\mathbf{4 5} \%$ dari jumlah karyawan tetap yang ada di lingkungan PG Lestari. Karekteristik karyawan yang menjadi subjek dalam penelitian ini relatif beragam, baik dari sisi jenis kelamin, umur, masa kerja, dan golongan. Keseluruhan subjek yang hadir mengisi 3 kuesioner yaitu a) Skala Orientasi Komitmen, b) Skala Kepercayaan terhadap Manajemen, dan c) Skala Kepernimpinan Transformasional

Penelitian ini bertujuan untuk menemukan hubungan orientasi komitmen karyawan dan masalah kepercayaan terhadap manajemen dengan kepemimpinan transformasional. Secara lebih mendalam, diharapkan akan dapat ditemukan pula beberapa hal, antara lain a) Hubungan antara kepemimpinan transformasional dan kepercayaan terhadap manajemen torhadap onientasi komitmen kani, b) Hubungan antara kepemimpinan transformasional dan kepercayaan terhadap manajemen terhadap orientasi komitmen kelompok, dan c) Hubungan antara kepemimpinan transformasional dan kepercayaan terhadap manajemen terhadap orientasi komitmen organisasi.

\section{Hasil}

Kepemimpinan transformasional dan kepercayaan terhadap manajemen mempunyai hubungan terhadap orientasi komilmen. Hal itu didasarkan pada hasil analisis regresi yang menunjukkan bahwa korelasi antara kepercayaan terhadap manajemen dan kepemimpinan transformasional dengan komitmen memiliki nilai $R=0,398$. Hanya saja korelasi antara kepercayaan terhadap manajemen dengan orientasi komitmen memiliki nilai $R=0,369$. Hal ini menunjukkan bahwa kepercayaan terhadap manajemen lebh memiliki korelasi yang tinggi terhadap orientasi komitmen. Hal ini diperkuat dengan hasil analisis korelasi parsial yang menunjukkan bahwa korelasi antara kepercayaan terhadap manajemen dan orientasi komitmen sebesar $\mathrm{r}$ $=0,2316$ dengan $p=0,001$ lebih besar daripada korelasi antara kepertimpinan transfomasional dan orientasi komitmen sebesar $r=0,1782$ dengan $p=0,010$.

Orientasi komitmen kari lebih dipengaruhi oleh kepercayaan terhadap manajemen. Kepemimpinan transformasional ketika disertai dengan kepercayaan terhadap manajemen memang semakin memperkuat pengaruh terhadap komitmen karir. Kepemimpinan transformasional itu sendiri tidak mempengaruhi komltmen. Berdasar hasi analisis uij t pasca regresi yang menunjukkan bahwa nilai $t$ pada variabel kepemimpinan transformasional $=1,233$ dengan $p=0.219$. $\mathrm{Hal}$ ini diperkuat dengan hasil analisis korelasi parsial yang menunjukkan bahwa korelasi antara kepercayaan terhadap manajemen dan orientasi komitmen karir sebesar $\mathbf{r}=0,2939$ dengan $\mathrm{p}=0,000$. Sementara itu, tidak ada korelasi antara kepemimpinan transformasional dan orientasi komitmen karir. Hal itu ditunjukkan dengan nilai $\mathbf{r}=0,0858$ dengan $p=0,219$.

Kepemimpinan transformasional dan kepercayaan pada manajemen mempunyai hubungan terhadap komitmen kelompok Hal itu didasarkan pada hasil analisis regesi yang menunjukkan bahwa korelasi antara kepercayaan terhadap manajemen dengan orientasi komitmen memiliki nilai $\mathbf{R}=0,369$, sedangkan korelasi antara antara kepercayaan terhadap manajemen dan kepemimpinan transformasional dengan komitmen memiliki nilaj $R=0,398$. Hal inj menunjukkan bahwa kepercayaan pada manajemen lebih menunjang terbentuknya komitmen kelompok. Hal ini diperkuat dengan hasit analisis korelasi 
parsial yang menunjukkan bahwa korelasi antara kepercayaan terhadap manajemen dan orientasi komitmen kelompok sebesar $\mathrm{r}=$ 0,1850 dengan $p=0,008$ lebih besar daripada korelasi antara kepemimpinan transtomasional dan orientasi komitmen kelompok sebesar $r$ $=0,1610$ dengan $p=0,020$.

Orientasi komitmen organisasi lebih dipengaruhi oleh kepemimpinan transformasional. Meski demikian kepemimpinan transformasional ketika disertai dengan kepercayaan terhadap manajemen memang semakin memperkuat pengaruh terhadap komitmen, namun demikian kepercayaan terhadap manajemen itu sendiri tidak mempengaruhi orientasi komitmen organisasi. Hal itu didasarkan pada hasil analisis uji t pasca regresi yang menunjukkan bahwa nilai tpada variabel kepercayaan terhadap manajemen $=$ 1,571 dengan $p=0.118$. Hal ini diperkuat dengan hasil analisis korelasi parsial yang menunjukkan bahwa korelasi antara kepemimpianan transformasional dan orientasi komitmen organisasi sebesar $r=0,1750$ dengan $p=0,012$. Sementara itu, tidak ada korelasi antara kepercayaan terhadap manajemen dengan dan orientasi komitmen organisasi. Hal itu ditunjukkan dengan nilai $r=$ 0,1091 dengan $p=0,118$.

\section{Pembahasan}

Hal inl berarti bahwa kepemimpinan transformasional akan lebih efektif dan berpengaruh apabila kepercayaan terhadap manajemen sudah terasakan oleh para pengikut organisasi atau karyawan. Hal ini sejalan dengan Podsakoff, MacKenzie, \& Bommer (1996) menegaskan bahwa perilaku kepemimpinan transformasional mempengaruhi aspek kepercayaan terhadap organisasi maupun komitmen.

Hal penting dari hasi penelitian ini terletak pada posisi hubungan ketiga variabel tersebut. Dengan kata lain, orientasi komitmen karyawan tidak akan terbentuk secara kuat, manakala kepercayaan terhadap manajemen belum dirasakan secara langsung oleh para pengikut. Peran aspek kepercayaan terhadap manajemen dalam hal ini cukup kuat.

Dalam konteks penelitian ini, seorang pemimpin yang menjalankan konsep kepemimpinan transformasional diharapkan untuk dapat membangun suasana yang menyebabkan para karyawan percaya terhadap manajemen. Kepercayaan ini lebih difokuskan pada aspek kemampuan, kebijakan, dan integritas sang pemimpin. Hal ini menjadi sesuatu yang pertu ditekankan, karena budaya organisasi di lingkungan Asia memang masih memerlukan itu sebagai pijakan awal untuk membangun komitmen karyawan.

Menurut kajian Ahmed (dalam Putti, Koontz, \& Weihrich, 1998), d beberapa negara Asia, seorang pemimpin akan dipercaya dan dianggap manakala sang pemimpin memiliki kemampuan mengkoor dinasi. Oleh karenanya, sang pemimpin tersebut harus memiliki karakteristik seperti sopan, berusaha menghindari konfrontasi, adaptif, memiliki kemauan belajar, mampu menumbuhkan orang lain berpendapat, dan sadar akan status. Apabila dikaji secara lebih mendalam, karakteristik tersebut amat berkaitan dengan konsep kepercayaan terhadap manajemen yang dikembangkan oleh Mayer, Davis, dan Schooman (1995).

Hal tersebut juga didasari dengan pernyataan Tjosvold \& Tjosvold (1995) yang me negaskan pentingnya relasi antara pernir pin dan pengikut bersifat kostruktif, saling percaya den saling respek. Hal tersebut juga didukung dengan pandangan Synder, Dowd, \& Houghton (1994) yang menekankan aspek pember-dayaan pengikut. Sebagaimana diketahui, proses pemberdayaan ini baru akan erjadi manakala ada saling percaya antar sang pemimpin dan pengikut.

Berdasarkan hasil penelitian menunjukkan bahwa peran kepemimpinan transformasional tidak begitu berpengaruh secara statistik terhadap komitmen terhadap kari. Komitmen karir lebih dipengaruhi oleh kepercayaan terhadap manajemen. Salah satu alasannya adalah fokus antara kepemimpinan transformasional cenderung berbeda dengan fokus 
komitmen terhadapa karir. Dalam kepemimpinan transformasional lebih cenderung menekankan pada upaya untuk memberikan inspirasi bagi anak buah untuk berbuat demi organisasi (Wood dkk, 1998). Sementara itu, komitmen terhadap karir lebih memfokuskan sistem pengembangan karir. Hal ini berarti berkaitan dengan masabh sistem yang berlaku padaorganisasi dan proses implementasinya. Permasalahannya adalah sudahkah sistem yang dijalankan oleh manajemen memang dapat dipercaya dan dilakukan secara adil.

Temuan lan tentang pola korelasi antara kepemimpinan transformasional dan kepercayaan terhadap manajemen, dengan orientasi komitmen kelompok. Hal d atas mengindikasikan bahwa aspek kepercayaan terhadap manajemen lebih kuat dalam membangun komitmen terhadap kelompok. Olen sebab itu, secara tidak langsung dapatdikatakan bahwa kepe-mimpinan transformasional baru akan efehtif dalam membangun komitmen bak tertadap kelompok ketka membentuk kepercayaan terhadap manajemen. Manakala kepercayaan terhadap manajemen belum terasakan lebh dahulu, maka kepemimpinan transformasional penganuhnya kurang terthat.

Fenomena yang terjadi di atas dapat difahami karena komitmen terhadap kelompok merupakan proses yang berkaitan dengan aspek relasi sosial yang sangat kuat. Menurut Tyler dan Degoey (dalam Karamer \& Tyler, 1997), kepercayaan merupakan sesuatu hal yang penting ketika orang memiliki hubungan sosial. Dalam konteks ini, orang lain atau karyawan akan merasa memiliki komitmen secara kelompok, manakala ia dipimpin oleh orang yang layak dipercaya untuk memperkuat relasi sosial. Sementara itu, pemimpin yang layak dipercaya memang akan mudah ter jadi manakala ia dipandang sebagai sosok yang mampu memahami nilai-nilai pengikutnya.

Temuan yang mengindikasikan bahwa orientasi komitmen terhadap organisasi lebih dipengaruhi oleh kepemimpinan transformasional. Temuan ini semakin mengukuhkan pandangan YukJ (1998) yang mengemukakan bahwa kepemimpinan trans- formasional memang akan memberikan pengaruh terhadap komitmen organisasional dari sisi kolaborasi antara pimpinan dan anak buah sebagai satu kesatuan kelompok yang diikat oleh satu visi. Dalam kasus ini kohesivitas akan tinggi dan sang pemimpin cenderung berperan sebagai fasilitator dalam proses pemberdayaan (Bradford \& Cohen, 1998). Perasaan satu tim yang diarahkan dengan satu hal atau visi hilah yang banyak mendorong terciptanya suatu komitmen terhadap organisasi.

Berdasarkan hasil penelitian dan pembahasan secara mendalam, dapat diambil beberapa kesimpulan.

1. Orientasi kormitmen lebh berkaitan dengan kepercayaan terhadap manajemen, tetapi juga tetap didukung oleh peran kepemimpinan transformasional.

2. Orientasi komitmen karir lebih berkaitan dengan kepercayaan terhadap manajemen. Sementara itu, kepemimpinan transformasional tidak mempengaruhi terbentuknya terbentuknya orientasi komitmen karis.

3. Orientasi komitmen kelompok lebih berkatan dengan kepercayaan tertadap manajemen, tetapi juga tetap didukung oleh peran kepemimpinan transformasional.

4. Orientasi komitmen organisasi lebih berkaitan dengan peran kepemimpinan transformasional. Sementara itu, kepercayaan terhadap manajemen tidak mempengaruhi terbentuknya erbentuknya orientasi komitmen organisasi.

\section{DAFTAR PUST:AKA}

Bass, B. M. 1985. Leadership and Pefor. mance Beyond Expectation. New York Free Press

Bass, B. M. \& Avolio, B. I (Eds). 1994, increasing Organizational Eflactiveness through Transfomational Leadership. Thousand Oaks, CA: Sage

Bradford, D.L \& Cohen, A. R. 1998. Powerup: 
Transforming Organizations Through Shared Leadership. Singapore: Jon Willey \& Sons, Inc.

Brett, J. F, Cron, W. L., \& Slocun, J. W. 1995. Economic Dependency on Work AModerator of the Relation between Organizational Commitment and Performance. Academy or Management Joumal, 38, 261-271

Gross, D. 1996. Forbes; Kisah-Kisah Bisnis Terbesar Sepanjang Masa. Ath bahasa: Anton Adiwiyoto, Jakarta: Professional Books

Hughes, R L., Ginnet, R C., \& Curphy, G J. 1999. Leadership Enhanaing The Lesson of Experience Singapore: McGraw-Hill

Irianto, Isrok. 1991. Pengaruh Pola Kepemimpinan Transformasional Indonesia terhadap Perubahan: Sebuah Kasus Kepemimpinan di PT Wijaya Karya Jakarta. Tesis (Tidak diterbitkan) . Bandung: Program Magister Teknik \& Manjemen Industri Pascasarjana ITB.

Kramer, $\mathrm{R} \mathrm{M}_{1,}$ \& Tyler, T. R 1996. Thust in Onganizations: Fronters of Theory and Research. Calfornia: Sage Publications. he.

Mayer, R.C., Davis, J. H., \& Schoorman, F. D. 1995. An Integrative Model of Organizational Trust Academy of Management Review, 20, 709.734

Podsakotf, P. M., Mackenzie, S. B., \&
Bommer, W. H. 1996. Transformational Leader Behaviors and Subtitutes for Ladership as Deterrminants of Employee Satisfaction, Commitment, Trust, and Organizational Citizenship Behavior. Joumal of Management. Vol. 22 No. 2 , 259298

Putti, J.M., Koontz, H., \& Weihrich, H, 1998. Essentia's of Management: An Asian Persperctive. Singapore: McGraw-Hill Book. Co.

Synder, N.H., Dowd Jr. J.J., \& Houghton 1994. Vision, Values, and Courag: Lesdership for Quality Management. Singapore: The Free Press.

Tjosvold, D. \& Tjosvold, M.M., 1995. Psychofogy for Leader. Singpore: John Wiley \& Sons, Inc.

Walker, JW. 1991. Human Resources Strategy. New York: McGraw Hill

Wexley, K N. \& Yuki, G. A. 1977. Organizational Behavior and Personnel Psychology. Illinois: Richard D. Irwin, Inc.

Wood, J etal. 1998. Onganisationa/Behaviour: An Asia-Pacific Perspective. Australian edition, Milton:: Jacaranda Wiley LTD

Yuki, G 1998. Leadership in Organizations. Now Jersey: Prentice-Hall inc. 